\title{
HYPOXIA AND REPRODUCTIVE HEALTH Oxygen and development of the human placenta
}

\author{
Graham J Burton $\mathbb{1}^{1,2}$, Tereza Cindrova-Davies ${ }^{1,2}$, Hong wa Yung ${ }^{1,2}$ and Eric Jauniaux ${ }^{3}$ \\ ${ }^{1}$ Centre for Trophoblast Research, University of Cambridge, Cambridge, UK, ${ }^{2}$ Department of Physiology, \\ Development and Neuroscience, University of Cambridge, Cambridge, UK and ' $E G A$ Institute for Women's Health, \\ Faculty of Population Health Sciences, University College London (UCL), London, UK \\ Correspondence should be addressed to G J Burton; Email: gjb2@cam.ac.uk
}

This paper forms part of a special section on Hypoxia and Reproductive Health. The guest editor for this section was Dr Jacqueline A Maybin (University of Edinburgh, UK)

\begin{abstract}
Development of the human placenta takes place in contrasting oxygen concentrations at different stages of gestation, from $\sim 20$ $\mathrm{mmHg}$ during the first trimester rising to $\sim 60 \mathrm{mmHg}$ at the start of the second trimester before gradually declining to $\sim 40 \mathrm{mmHg}$ at term. In view of these changes, the early placenta has been described as 'hypoxic'. However, placental metabolism is heavily glycolytic, supported by the rich supply of glucose from the endometrial glands, and there is no evidence of energy compromise. On the contrary, the trophoblast is highly proliferative, with the physiological low-oxygen environment promoting maintenance of stemness in progenitor populations. These conditions favour the formation of the cytotrophoblastic shell that encapsulates the conceptus and interfaces with the endometrium. Extravillous trophoblast cells on the outer surface of the shell undergo an epithelialmesenchymal transition and acquire invasive potential. Experimental evidence suggests that these changes may be mediated by the higher oxygen concentration present within the placental bed. Interpreting in vitro data is often difficult, however, due to the use of non-physiological oxygen concentrations and trophoblast-like cell lines or explant models. Trophoblast is more vulnerable to hyperoxia or fluctuating levels of oxygen than to hypoxia, and some degree of placental oxidative stress likely occurs in all pregnancies towards term. In complications of pregnancy, such as early-onset pre-eclampsia, malperfusion generates high levels of oxidative stress, causing release of factors that precipitate the maternal syndrome. Further experiments are required using genuine trophoblast progenitor cells and physiological concentrations to fully elucidate the pathways by which oxygen regulates placental development.
\end{abstract}

Reproduction (2021) 161 F53-F65

\section{Introduction}

Oxygen is thought to play a major role in modulating human placental development, which is perhaps not surprising given that this foetal organ evolved principally for the maternal-foetal transfer of respiratory gases. The placenta is unusual in that it has two blood supplies, the maternal utero-placental circulation that supplies oxygen and nutrients and the feto-placental or umbilical circulation that abstracts these to meet the needs of the growing foetus. The balance between supply and demand will determine the oxygen $\left(\mathrm{O}_{2}\right)$ concentration within the placental tissues, and it is now appreciated that this concentration varies across gestation. In this regard, pregnancy can no longer be considered a continuum but as a process that has two distinct phases, the first trimester lasting until the end of week 12 and the second and third trimesters extending until term. These phases correspond to the embryonic and foetal periods of development, respectively. The transition is associated with a three-fold rise in the intraplacental $\mathrm{O}_{2}$ concentration that must be spatially co-ordinated, for it represents a significant challenge to the placental tissues. Failure of the transition to occur correctly is associated with complications of pregnancy ranging from miscarriage to pre-eclampsia.

Central to any consideration of $\mathrm{O}_{2}$ is the concept of generation of free radicals, molecular species with unpaired electrons. The superoxide anion $\left(\mathrm{O}_{2}{ }^{-}\right)$is constantly formed under aerobic conditions within mitochondria due to the leakage of electrons from the enzymatic complexes of the electron transport chain on to molecular $\mathrm{O}_{2}$, in particular from complex III. The rate of formation is proportional to the prevailing $\mathrm{O}_{2}$ concentration, and under physiological conditions, superoxide acts as an important signalling intermediate, regulating gene expression and cell metabolism to suit the prevailing conditions. If, however, production exceeds the antioxidant defences, then indiscriminate damage can occur to any biomolecule in the immediate 
vicinity, often initiating chain reactions. This condition is referred to as oxidative stress and may lead to inflammation, senescence, apoptosis and necrosis. Placental oxidative stress lies at the heart of many complications of pregnancy. It is induced primarily through malperfusion of the placenta, but may be exacerbated by deficiencies in the maternal antioxidant defences caused by malnutrition or genetic mutations.

\section{Oxygen and implantation}

Fertilisation takes place in the ampullary region of the Fallopian tube, following which the differentiating morula travels down the oviduct and enters the uterus at around day 5 p.c. (post-conception). The prevailing partial pressure of $\mathrm{O}_{2}\left(\mathrm{PO}_{2}\right)$ within the uterus during the non-pregnant cycle has been reported to average between $15 \mathrm{mmHg}$ (Yedwab et al. 1976) and 18.9 $\mathrm{mmHg}$ (Ottosen et al. 2006), although considerable variation is observed between women. Although no data are available, similar values might be expected at the time of implantation. A relatively low $\mathrm{PO}_{2}$ is thought to be optimal for early development, for it helps to maintain metabolism in what has been referred to as a 'quiet' state, reliant on endogenous reserves (Leese 2002). Production of reactive oxygen species (ROS), free radicals and their non-radical intermediates such as hydrogen peroxide, is kept to a minimum. This limits oxidative damage to the zygotic DNA and disruption of intracellular signalling pathways at this critical stage of development.

There is mounting evidence that embryo culture at a low $\mathrm{O}_{2}$ level (5\%) compared to atmospheric level during in vitro fertilization procedures improves pregnancy rates in humans, and thus may have an impact on both embryonic development and implantation (Bontekoe et al. 2012, Van Montfoort et al. 2020). In particular, a low $\mathrm{O}_{2}$ level in the culture medium produces more (Gelo et al. 2019), and better-quality (Van Montfoort et al. 2020), blastocysts. This effect was originally reported by Steptoe, Edwards and Purdy in their classic Nature article in 1971 on the first successful culture of a human embryo to the blastocyst stage (Steptoe et al. 1971). However, for decades embryo culture has been performed at atmospheric levels, probably due to the additional technical cost of using equipment to reduce the $\mathrm{O}_{2}$ concentration in the culture medium.

Implantation occurs into the superficial endometrium, starting around day 7 p.c. with attachment of the blastocyst to the uterine epithelium equidistant from the openings of the endometrial glands. By day 11 the blastocyst has been encapsulated by overgrowth of the endometrium and so is removed from the uterine lumen. By this time, the trophectoderm that formed the outer wall of the blastocyst has differentiated into the syncytiotrophoblast in contact with the decidua and an underlying population of progenitor cells, the cytotrophoblast. As the syncytiotrophoblast enlarges, it erodes into the superficial capillary plexus within the endometrium and maternal erythrocytes are released into the forerunners of the intervillous space (Hamilton \& Boyd 1960). The presence of these erythrocytes within the developing placenta was taken by many embryologists as indicative of a maternal circulation to the organ, and is still depicted as such in many standard textbooks of embryology. However, in these early descriptions it was noted that the erythrocytes are relatively few in number and stain weakly compared to counterparts in nearby vessels, features that led the authors to question how active the circulation is at this stage of development beyond a venous ebb and flow.

\section{The placental microenvironment during the first trimester}

A series of observations and measurements taken in the 1980s and 1990s clarified the situation, and it is now widely accepted that there is little, if any, maternal arterial inflow into the placenta until towards the end of the first trimester. Ultrasonographic signals indicative of significant flow cannot be detected within the intervillous space prior to this time point (Hustin \& Schaaps 1987, Jauniaux et al. 1991), yet are present within arteries in the underlying endometrium. Histological studies revealed that this difference is due to aggregates of extravillous trophoblast (EVT) cells within the spiral arteries. These cells are derived from the cytotrophoblastic shell, a multi-layered capsule of EVT that surrounds the conceptus at this stage, sealing it off and creating a protective milieu for the embryo (Burton \& Jauniaux 2017).

As the conceptus and the shell enlarge, the EVT come into contact with the tips of the spiral arteries. Cells from the outer surface of the shell differentiate into endovascular EVT that migrate down their lumens as part of the remodelling process (Pijnenborg et al. 2006). These cells migrate in such numbers that the mouths of the arteries are obstructed, restricting flow to a seepage of plasma through a network of intercellular spaces (Hustin et al. 1988, Burton et al. 1999, Roberts et al. 2017). Hence, for most of the first trimester, the placental intervillous space is filled with a clear fluid, comprising maternal plasma supplemented with secretions from the endometrial glands (Hustin \& Schaaps 1987, Schaaps \& Hustin 1988, Burton et al. 2002). Confirmation of the absence of significant maternal erythrocytes was provided by measurements of the oxygen concentration within the developing placenta taken with a multiparameter probe prior to termination of pregnancy at gestational ages ranging from 7 to 16 weeks. Values of $\sim 18 \mathrm{mmHg}$, or approximately $2.5 \% \mathrm{O}_{2}$, were recorded prior to 10 weeks of pregnancy, very similar to those within the uterus during the non-pregnant cycle. 
These rose to $\sim 60 \mathrm{mmHg}$, or approximately $8 \% \mathrm{O}_{2}$, at 14 weeks (Rodesch et al. 1992, Jauniaux et al. 2000, 2001), when the progressive formation of channels within the trophoblastic aggregates and changes in the arcuate arteries lead to increased arterial inflow into the intervillous space (Burton et al. 1999, Roberts et al. 2017).

The three-fold rise in oxygenation at the start of the second trimester has led to the early placenta commonly being described as hypoxic. However, hypoxia cannot be defined by the prevailing $\mathrm{O}_{2}$ concentration alone, for the definition must consider the metabolic needs of the tissue concerned. When the $\mathrm{O}_{2}$ concentration drops so low that these needs can no longer be met, a cell must adapt to conserve resources, switching its metabolism and activities from oxyregulating to oxyconforming (Gorr 2017). The critical level, or $P_{C_{1}}$ at which this occurs defines the normoxia/hypoxia boundary for that cell type; for most mammalian cell types the threshold is within the $\sim 0.15-1.5 \% \mathrm{O}_{2}$ range (Gorr 2017). Cells with substantial energy demands due to high rates of proliferation, active transport, or protein synthesis and secretion will be more sensitive to $\mathrm{O}_{2}$ lack than their more sedentary counterparts. This is true within the placenta, for BeWo cells that are considered similar to the endocrine syncytiotrophoblast show a greater reduction in proliferation rates and more severe molecular adaptations at $1 \% \mathrm{O}_{2}$ than isolates of placental fibroblast stromal cells (Yung et al. 2012).

The value of $\mathrm{P}_{\mathrm{C}}$ has not been determined for human placental cell types, and, therefore proxy markers have to be used as a guide to hypoxic stress. These include activation of members of the HIF (hypoxiainducible factor) family that act as master regulators of cell metabolism in response to oxygen availability, showing maximum activity around the $\mathrm{P}_{C}$ (Gorr 2017). Data relating to HIF need to be interpreted with caution, however, for many factors can lead to its stabilisation, including cytokines and hyperoxia (Pringle et al. 2010). Thus the mode of collection of the placental samples is critically important. In first trimester samples removed by a chorionic villus sampling (CVS) technique, during which the sample does not come into contact with maternal blood, no stabilisation of HIF-1 is observed. By contrast, in samples removed by the standard method of suction-curettage when they are inevitably exposed to maternal blood, or if CVS samples are cultured under atmospheric $\mathrm{O}_{2}$ concentrations or with hydrogen peroxide, then HIF-1 can be detected (Cindrova-Davies et al. 2015). Such samples also display phosphorylation of p38, indicative of a cell stress response. These findings demonstrate that the HIF pathway is present and can be activated during early pregnancy, but that under physiological conditions levels are too low to be detected by Western blotting. Binding of HIF to DNA may provide a more sensitive read-out of the role of HIF signalling following implantation.
Other proxy markers of hypoxia are the ATP/ADP ratio and activation of AMP kinase that signals low energy status within a cell. The ratio was found to be constant across homogenates of placental villi sampled from first-, second- and third-trimester placentas (CindrovaDavies et al. 2015). Although homogenisation of tissue will mask possible differences between cell types, the data provide no evidence of overall energy deficiency in these tissues.

The reason for this constancy may be three-fold. First, the oxygen concentration measured during the first trimester was $2.5 \%$, which is above the hypoxic range for most cell types and equivalent to that in resting muscle and other healthy tissues. Secondly, phylogenetically old carbohydrate metabolic pathways, the polyol pathways, are highly active in placental tissues, particularly during the first trimester but also throughout pregnancy (Jauniaux et al. 2005). These pathways, which are closely interlinked to the pentose phosphate pathway, regenerate $\mathrm{NAD}^{+}$and $\mathrm{NADP}^{+}$through the formation of sugar alcohols, such as ribitol, sorbitol and erythritol. Thus, glycolysis can be maintained without undue dependence on fermentation and production of lactate (Jauniaux et al. 2001, Burton et al. 2017b). Reliance on glycolysis rather than oxidative phosphorylation for energy production has the added advantage that carbon skeletons are preserved and can be used in the synthesis of nucleotides needed to support the high rate of cell proliferation, rather than being broken down and excreted as carbon dioxide. Finally, the histotrophic secretions from the endometrial glands contain large amounts of glucose and glycogen and hence can support a high rate of placental glycolysis.

Overall, although the $\mathrm{O}_{2}$ concentration within the placenta is lower during the first trimester than later in pregnancy, there is no evidence that the tissues are hypoxically stressed. Indeed, hypoxia would be incompatible with the high rate of proliferation observed, for suppression of protein synthesis, a pre-requisite for cell division, is one of the principal adaptations when $\mathrm{O}_{2}$ availability becomes limiting (Hochachka \& Lutz 2001).

\section{Oxygen as a modulator of trophoblast proliferation}

The low-oxygen environment during the first trimester likely facilitates placental development in a number of ways, although the experimental data are often conflicting and difficult to interpret. In part, the latter is due to the fact that until recently a trophoblast stem/progenitor cell that proliferates in vitro has not been available (Haider et al. 2018, Okae et al. 2018, Turco et al. 2018). Consequently, researchers have had to rely on trophoblast-like cell lines. Some of these are derived from choriocarcinomas, such as the JEG3 and BeWo lines, and may have highly atypical metabolism and invasive behaviour, whereas others, such as the 
HTR-8/SVneo, have been immortalised. Different cell lines reflect particular trophoblast sub-types, for example, BeWo and JAR cells are considered close to the villous cytotrophoblast lineage, whereas the HTR-8/ SVneo and JEG-3 lines are more closely aligned to the extravillous lineage (Apps et al. 2011). Hence, the various lines may respond in different ways reflective of their origin. In addition, all these cell lines have been cultured under ambient oxygen concentrations for many years and so are fully adapted to $20 \%$ oxygen. Their responses to low oxygen may therefore be very different from the in vivo situation. In addition, they are often grown in standard culture medium that contains non-physiological concentrations of glucose, permitting maintenance of glycolysis at high levels. Adaptation to physiological concentrations not only renders the cells more susceptible to hypoxia-reoxygenation, but also enables the unfolded protein responses observed in placentas from cases of early-onset pre-eclampsia to be fully recapitulated in vitro (Yung et al. 2014, 2019). Serum supplementation, and if so the concentration used, is another confounding variable that can influence the physiological buffering capacity of the culture medium. For all these reasons, data derived from the use of cell lines therefore needs to be interpreted with caution.

Alternatively, use has been made of villous explants, grown usually on a Matrigel substrate. Outgrowth of cells from the villous tip is often measured as an estimate of EVT proliferation and differentiation, but accurate quantification is impossible in this model as the starting number of cytotrophoblast cells in an individual explant is not known. Instead, the proportion of cells staining positively for a marker of proliferation can be used as a measure. Another limitation of many in vitro experiments is that comparisons have been performed between non-physiological $\mathrm{O}_{2}$ concentrations, both high and low. Commonly, controls are cultured at 21\% $\mathrm{O}_{2}$ and considered 'normoxic', whereas in reality these are hyperoxic for primary cultures and villous explants. Equally, others have used $0 \%$ or $0.5 \%$ to stimulate a hypoxic response, which is unlikely to be compatible with an ongoing pregnancy. Nonetheless, some generalities emerge.

First, maintenance of stem cells and pluripotency is favoured under conditions of $2-5 \% \mathrm{O}_{2}$, modulated through stabilisation of HIF family members through ROS generated within mitochondria (Forristal et al. 2013, Lees et al. 2017). For example, HIF2 $\alpha$ binds to hypoxia response elements in NANOG, OCT4 and SOX2, maintaining the pluripotency network in human embryonic stem cells under physiological $\mathrm{O}_{2}$ levels, but not under atmospheric conditions (Lees et al. 2017). Consistent with this finding, human embryonic stem cells cultured under $5 \% \mathrm{O}_{2}$ show less differentiation and production of human chorionic gonadotropin than those grown under $21 \% \mathrm{O}_{2}$ (Ezashi et al. 2005, Lengner et al.
2010). In the human placenta, the transcripts and protein levels of two key transcription factors that characterise the trophoblast stem cell population, CDX2 and ELF5, decrease sharply at the end of the first trimester (Hemberger et al. 2010, Burton et al. 2020). This reduction in stemness is associated with increased methylation of the ELF5 promoter region, and proliferation becomes restricted to a niche located at the proximal end of a cytotrophoblast cell column (Burton et al. 2020). Whether this change is secondary to the rise in oxygenation or the loss of growth factor support from the endometrial glands is uncertain at present.

Secondly, several studies have shown that proliferation of trophoblast cells is promoted under $2-3 \% \mathrm{O}_{2}$ compared to $21 \%$ controls (Table 1 ). Thus, primary cultures of cytotrophoblast cells isolated from 10- to 12-week-old placentas showed a three-fold increase in the incorporation of bromodeoxyuridine (BrdU) when cultured in $2 \%$ oxygen compared to either $8 \%$ or $21 \%$ conditions (Genbacev et al. 1996). Similarly, villus explants of 6-8 weeks' gestational age displayed incorporation of BrdU into a greater proportion of cytotrophoblast cells and more extensive formation of cell columns when cultured for $72 \mathrm{~h}$ under $2 \%$ oxygen rather than 21\% (Genbacev et al. 1997). Similar findings were reported using the proliferation marker Ki67 in 5to 8-week-old villous explants cultured for 5 days under $3 \%$ compared to $21 \% \mathrm{O}_{2}$, which could be reversed by knocking down HIF-1 $\alpha$ (Caniggia et al. 2000).

By contrast, opposite results have generally been presented using trophoblast-like cell lines (Table 1) (Lash et al. 2007). This difference most likely reflects the fact that, as mentioned earlier, these lines have become acclimatised to ambient oxygen concentrations over the years and adjusted their metabolism accordingly.

The $\mathrm{O}_{2}$ levels used in such experiments are likely to be critical, for recently it was found that $\mathrm{BrdU}$ incorporation into 5- to 8-week-old explants is reduced under $1 \% \mathrm{O}_{2}$ compared to either $5 \%$ or $20 \% \mathrm{O}_{2}$, with no difference between the latter two levels (Treissman et al. 2020). However, $1 \% \mathrm{O}_{2}$ is within the hypoxic range for most cells (Gorr 2017) and may be considered non-physiological. At these levels, cells reduce protein synthesis and proliferation to conserve resources, mediated through activation of the unfolded protein response pathways (Wouters et al. 2005). This interpretation is supported by the finding that proliferation of murine trophoblast stem cells is greatest under $2 \% \mathrm{O}_{2}$, lower under $20 \%$ and least under either $0.5 \%$ or $0.0 \% \mathrm{O}_{2}$ (Zhou et al. 2011). Furthermore, levels of phosphorylated stress-activated protein kinase (pSAPK) were highest in the cells cultured under $0.5 \%$ or $0.0 \% \mathrm{O}_{2}$, when they were associated with activation of the apoptotic cascade. Overall, therefore, it appears that trophoblast proliferation and maintenance of multipotency (Zhou et al. 2011) are greatest under the physiological conditions of $2-3 \% \mathrm{O}_{2}$ prevailing during the first trimester. 
Table 1 Summary of responses of different models to low oxygen conditions compared to the control.

\begin{tabular}{|c|c|c|c|c|c|c|}
\hline Study & Model & Oxygen & Proliferation & Outgrowth & Invasion & Apoptosis \\
\hline Genbacev et al. (1996) & $\begin{array}{l}\text { Primary cytotrophoblast } \\
10-12 \text { weeks }\end{array}$ & 2 vs 8 vs $20 \%$ & $\uparrow$ after $72 \mathrm{~h}$ & & $\downarrow$ after $72 \mathrm{~h}$ & \\
\hline Jiang et al. (2000) & $\begin{array}{l}\text { Primary cytotrophoblast } \\
\text { midterm }\end{array}$ & 2 vs $20 \%$ & $\uparrow$ after $72 \mathrm{~h}$ & & & \\
\hline Graham et al. (2000) & HTR-8/SVneo & 1 vs $20 \%$ & & & $\uparrow$ & \\
\hline Kilburn et al. (2000) & HTR-8/SVneo & 2 vs $20 \%$ & $\uparrow$ after $72 \mathrm{~h}$ & & $\downarrow$ after $72 \mathrm{~h}$ & \\
\hline Lash et al. (2007) & HTR-8/SVneo & 3 vs $20 \%$ & $\begin{array}{l}\downarrow \text { after } 48 \\
\text { and } 72 \mathrm{~h}\end{array}$ & & $\begin{array}{l}\uparrow \text { at } 24 \mathrm{~h} \\
\downarrow \text { after } 72 \mathrm{~h}\end{array}$ & $\begin{array}{l}\downarrow \text { after } 24 \\
\text { and } 48 \mathrm{~h}\end{array}$ \\
\hline Lash et al. (2007) & JEG-3 & 3 vs $20 \%$ & $\begin{array}{l}\downarrow \text { after } 24 \\
\text { and } 48 \mathrm{~h}\end{array}$ & & $\begin{array}{l}\uparrow \text { after } 24 \mathrm{~h} \\
\downarrow \text { after } 72 \mathrm{~h}\end{array}$ & $\begin{array}{l}\uparrow \text { after } 24 \\
\text { and } 48 \mathrm{~h}\end{array}$ \\
\hline Lash et al. (2007) & SGHPL-4 & 3 vs $20 \%$ & $\begin{array}{l}\downarrow \text { after } 24 \mathrm{~h} \\
\uparrow \text { after } 48 \mathrm{~h}\end{array}$ & & $\downarrow$ after $24 \mathrm{~h}$ & $\begin{array}{l}\uparrow \text { after } 24 \mathrm{~h} \\
\downarrow \text { after } 48 \mathrm{~h}\end{array}$ \\
\hline Lash et al. (2007) & JAR & & $\downarrow$ after $24 \mathrm{~h}$ & & & $\begin{array}{l}\uparrow \text { after } 24 \mathrm{~h} \\
\downarrow \text { after } 72 \mathrm{~h}\end{array}$ \\
\hline Yung et al. (2012) & JEG-3 & $1 \%$ vs $20 \%$ & $\downarrow$ after $72 \mathrm{~h}$ & & & \\
\hline Yung et al. (2012) & BeWo & $1 \%$ vs $20 \%$ & $\downarrow$ after $72 \mathrm{~h}$ & & & \\
\hline Caniggia et al. (2000) & $\begin{array}{l}\text { Explants } \\
\text { 5-8 weeks }\end{array}$ & 3 vs $21 \%$ & $\uparrow$ after $5 \mathrm{~d}$ & $\uparrow$ & $\downarrow$ & \\
\hline Genbacev et al. (1997) & $\begin{array}{l}\text { Explants } \\
6-8 \text { weeks }\end{array}$ & 2 vs $21 \%$ & $\uparrow$ after $72 \mathrm{~h}$ & $\uparrow$ after $72 \mathrm{~h}$ & $\downarrow$ after $72 \mathrm{~h}$ & \\
\hline Lash et al. (2006) & $\begin{array}{l}\text { Explants } \\
8-10 \text { weeks } \\
12-14 \text { weeks }\end{array}$ & 3 vs 8 vs $20 \%$ & - & & $\begin{array}{l}\downarrow \text { after } 6 \text { days } \\
\text { under } 3 \% \text { at both } \\
\text { gestational ages }\end{array}$ & - \\
\hline James et al. (2006) & $\begin{array}{l}\text { Explants } \\
8-12 \text { weeks }\end{array}$ & 1.5 vs $8 \%$ & & $\begin{array}{l}\downarrow \text { after } 5 \text { days in } \\
<11 \text { week samples }\end{array}$ & & \\
\hline Treissman et al. (2020) & $\begin{array}{l}\text { Explants } \\
\text { 5-8 weeks }\end{array}$ & 1 vs 5 vs $20 \%$ & $\downarrow$ under $1 \%$ & $\uparrow$ under 1 and $5 \%$ & & \\
\hline
\end{tabular}

\section{Oxygen as a modulator of trophoblast differentiation and invasion}

The effects of $\mathrm{O}_{2}$ on trophoblast differentiation into the EVT lineage and the subsequent invasiveness of these cells have been more controversial, and the same experimental caveats apply as for proliferation. The EVT are formed at the point where the placental villi make contact with the endometrium, at the tips of the anchoring villi. Here, the cytotrophoblast cells proliferate and in doing so form a cell column that at its distal end expands laterally, merging with neighbours to form the cytotrophoblastic shell that initially surrounds the conceptus (Fig. 1) (Burton \& Jauniaux 2017). The EVT lineage is characterised by a number of factors, including expression of HLA-G and matrix metalloproteinases, a change in integrin expression and loss of expression of p63. Experimental evidence indicates that the transition is regulated, in part at least, through complex interactions between the Notch and Wnt pathways (Nayeem et al. 2016, Haider et al. 2017). Notch 1 is localized to a subset of proliferating cells at the proximal end of the column and maintains these cells in a progenitor state (Haider et al. 2016). Expression and activity of Notch 1 are stimulated by low oxygen in vitro (Haider et al. 2016), and Notch signalling requires the presence of an intact HIF complex (Chang et al. 2018). Recent experiments utilising villous cytotrophoblast cells have demonstrated that differentiation into the EVT lineage is promoted under $2 \%$ compared to $20 \% \mathrm{O}_{2}$ and that the effect is mediated through HIF-1 $\alpha$ signalling (Wakeland et al. 2017).

As the cells progress down the column, they undergo maturation, and Wnt activity is thought to stimulate expression of MMP-2 in the more distal parts (Nayeem et al. 2016). The cells of the column and of the shell remain rounded in shape, however, and their position within the confines of the placenta indicates they are not particularly invasive. By contrast, cells on the outer surface of the shell in contact with the endometrium undergo an epithelial-mesenchymal transition and invade individually as spindle-shaped interstitial EVT into the stroma, where they surround the spiral arteries and endometrial glands. Interactions between these cells and maternal immune cells are considered to play a key role in remodelling the arteries and ensuring adequate perfusion of the placenta during the second and third trimesters (Moffett et al. 2015). Many complications of pregnancy arise as a failure of this invasion (Brosens et al. 2011), and so its regulation is a matter of great importance. In terms of the in vivo situation, it should be remembered that the interstitial EVT migrate up an $\mathrm{O}_{2}$ gradient, from $\sim 20 \mathrm{mmHg}$ in the placenta to $60-70 \mathrm{mmHg}$ in the endometrium during the first trimester and from $\sim 50 \mathrm{mmHg}$ to $70-80 \mathrm{mmHg}$ during the second trimester (Fig. 1) (Jauniaux et al. 2000, 2001). The extent of this gradient and the degree to which it involves the cell columns is unknown at present.

Experiments using primary cultures of cytotrophoblast cells or villous explants have demonstrated greater 


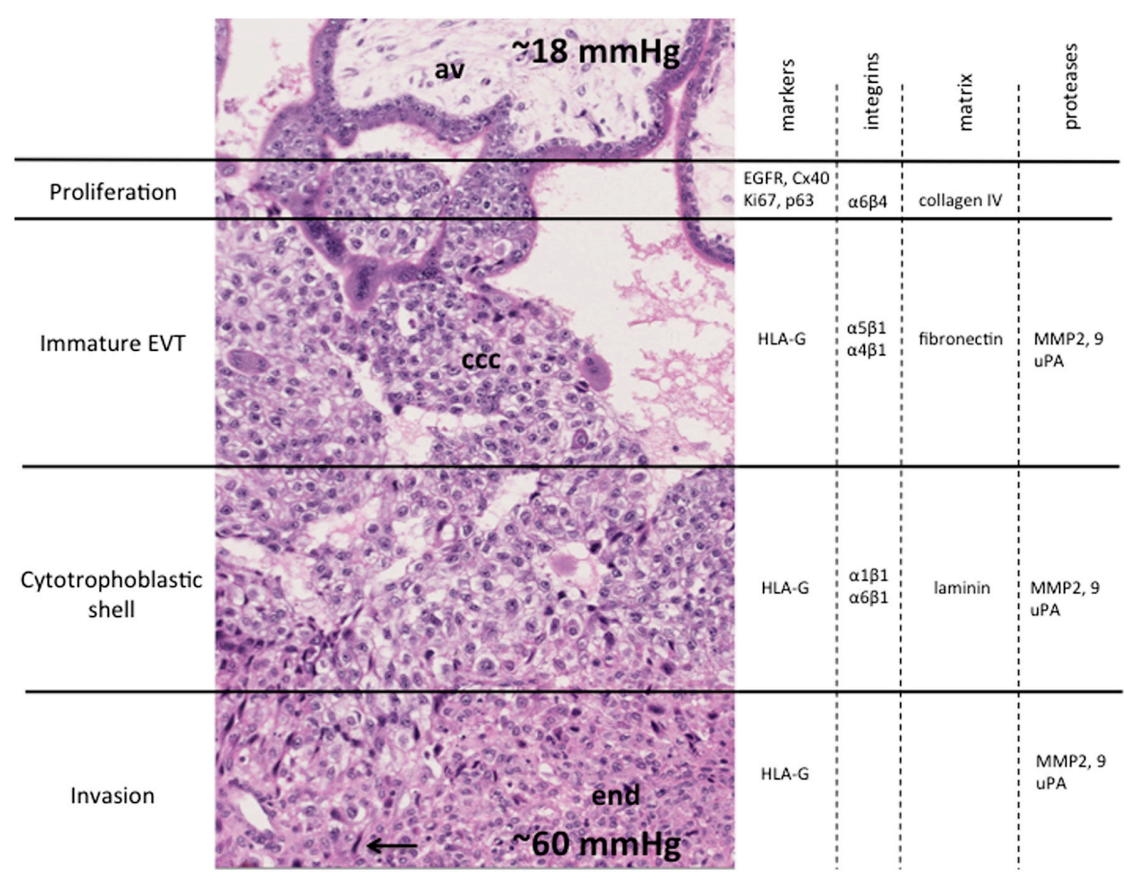

Figure 1 Photomicrograph of an anchoring villus (av) giving rise to a cytotrophoblast cell column (ccc) that is attached to the endometrium (end) of a specimen at 6 weeks of gestational age. Proliferation of the cytotrophoblast progenitors in the vicinity of the villous basement membrane and their differentiation into immature extravillous trophoblast (EVT) are promoted by the low $\mathrm{O}_{2}$ concentration within the placenta during the first trimester. The EVT cells on the maternal surface of the cytotrophoblast shell undergo a partial epithelial-mesenchymal transition, forming dark-staining spindle shaped cells that invade into the endometrium as interstitial EVT (arrowed). The invasion may be stimulated by the higher $\mathrm{O}_{2}$ concentration that always prevails in the endometrium. invasiveness in samples from the first trimester compared to the second and third trimesters or term (Genbacev et al. 1996, Lash et al. 2006). This change may reflect the transition in the intrauterine environment in vivo and highlights that gestational age is a potential confounding factor. Cytotrophoblast cells isolated from 10- to 12-weekold placentas cultured under $21 \% \mathrm{O}_{2}$ were several 100fold more invasive than those cultured under $2 \% \mathrm{O}_{2}$, consistent with the in vivo situation (Rodesch et al. 1992, Jauniaux et al. 2001) and potentially accounting for why EVT preferentially invade the maternal arteries rather than the veins (Genbacev et al. 1996, 1997).

These findings were supported by data from explant cultures derived from 5-to 8-week-old placentas (Table 1) (Caniggia et al. 2000). Culture under 3\% $\mathrm{O}_{2}$ was associated with higher levels of HIF- $1 \alpha$ than $20 \% \mathrm{O}_{2}$, which promoted proliferation of the cytotrophoblast progenitors and outgrowth at the villus tip. However, when HIF activity was blocked with antisense oligonucleotides, invasion of the EVT into the Matrigel, rather than just outgrowth over the surface, was promoted, facilitated by increased expression of matrix-metalloproteinase enzymes. The effects of HIF$1 \alpha$ were mediated through $\mathrm{TGF} \beta_{3}$ (Caniggia et al. 2000). Another study using the explant model also reported that invasion was reduced under $3 \% \mathrm{O}_{2}$ compared to $8 \%$ or $20 \%$ and was associated with changes in activity of the urokinase plasminogen activator system (uPA) (Lash et al. 2006). Contrary results were presented based on the immortalised HTR-8/SVneo trophoblast-like cell line, which showed increased invasion under $1 \% \mathrm{O}_{2}$ compared to $20 \%$ (Graham et al. 2000). Again, the changes were attributed to alterations in the uPA system.
Despite these differences, a consensus is developing that the low-oxygen environment within the placenta during the first trimester favours proliferation of the cytotrophoblast progenitors and their differentiation into immature EVT cells. Once the cells approach the decidua then the higher $\mathrm{O}_{2}$ concentration may stimulate further differentiation and the acquisition of the invasive phenotype (Chang et al. 2018, Treissman et al. 2020).

\section{The first-second trimester oxygen transition}

Ultrasonography has demonstrated that the onset of the maternal circulation starts preferentially in the peripheral margins of the early placenta, where trophoblast 'plugging' of the spiral arteries is least extensive (Jauniaux et al. 2003). Placental villi have low levels of the principal antioxidant enzymes during the first trimester compared to the second- and third trimesters. They are therefore vulnerable to oxidative stress, and villi removed from the periphery exhibit higher levels of oxidative damage, trophoblast degeneration and activation of the apoptotic cascade than counterparts in the central region (Jauniaux et al. 2003, Burton et al. 2010). These findings have led to the concept that local high levels of $\mathrm{O}_{2}$ created during onset of the maternal circulation may induce regression of the villi over the superficial pole of the chorionic sac, creating the chorion laeve and the definitive discoid placenta and the formation of the free placental membranes. Local variations in onset of the blood flow may lead to areas of excessive regression, resulting in abnormal placental shapes with eccentric cord insertions (Burton et al. 2010). 


\section{The placental microenvironment during the second and third trimesters}

It is estimated that 30-40 spiral arteries deliver maternal blood to the mature placenta. Despite extensive remodelling of the arteries in early pregnancy that causes dilation of the terminal segment and hence a reduction in velocity and pressure (Burton et al. 2009), the force of the inflowing blood sculpts the placental villi into a series of lobules. Each lobule resembles an inverted wine glass, with a relatively villus-free central cavity situated over the mouth of the spiral artery (Fig. 2). Oxygenated blood is delivered into the centre and then percolates between the villi, exchanging $\mathrm{O}_{2}$ and nutrients with the foetal circulation as it does so. Although no direct measurements have been taken, the centre of the lobule is assumed to be an arterial zone, while the peripheral regions equate to a venous zone. Expression levels of mRNAs encoding the principal antioxidant enzymes support this pattern (Hempstock et al. 2003b), as does recent MRI imaging (Hutter et al. 2019, 2020). Furthermore, villi in the periphery contain a greater volume of foetal capillaries and have a thinner interhaemal membrane than those in the centre (Fox 1967). Similar changes are seen in placentas from pregnancies at high altitude, when they facilitate gaseous exchange as the partial pressure of $\mathrm{O}_{2}$ is reduced (Espinoza et al. 2001).

Placental and foetal extraction of $\mathrm{O}_{2}$ increase with advancing gestation and so the $\mathrm{O}_{2}$ concentration in the peripheral region of a lobule will decrease. The deoxygenation will be exacerbated by the reduction in placental perfusion with increasing gestational age
(Sohlberg et al. 2014a). Samples of maternal blood aspirated from the subchorial lake beneath the chorionic plate confirmed a reduction in $\mathrm{PO}_{2}$ from $\sim 60 \mathrm{mmHg}$ at 16 weeks to $\sim 40 \mathrm{mmHg}$ at term (Fig. 3) (Soothill et al. 1986). Slightly lower values of $\sim 30 \mathrm{mmHg}$ have been obtained from women breathing air at the time of caesarean delivery (Schaaps et al. 2005). This gradual decline is thought to stimulate placental angiogenesis and the formation of terminal villi, which increases exponentially starting at around 20 weeks of gestation. The reduction does mean, however, that there is less $\mathrm{O}_{2}$ reserve within the maternal blood contained within the intervillous space. Any intermittency in maternal inflow will therefore have a more profound impact on placental oxygenation. The use of BOLD MRI imaging has revealed reductions in placental oxygenation lasting $2-4 \mathrm{~min}$ as a result of subclinical uterine contractions (Sinding et al. 2016). Consequently, there are likely to be fluctuations in $\mathrm{O}_{2}$ concentration that increase in severity towards term.

Hypoxia-reoxygenation is a powerful stimulus of oxidative stress in the placenta, both in vitro (Hung et al. 2001) and in vivo during labour (Cindrova-Davies et al. 2007), much more than hypoxia alone (Hung et al. 2001). Even the normal placenta is therefore likely to experience a degree of oxidative stress towards term (Fig. 3) (Cox \& Redman 2017). This may explain the increase in maternal concentration of the soluble receptor for VEGF, sFlt-1, and the decline in placental growth hormone, PIGF, seen towards term, for the former is positively regulated by oxidative stress (CindrovaDavies et al. 2007), while the latter is negatively regulated by the related endoplasmic reticulum stress (Mizuuchi et al. 2016).

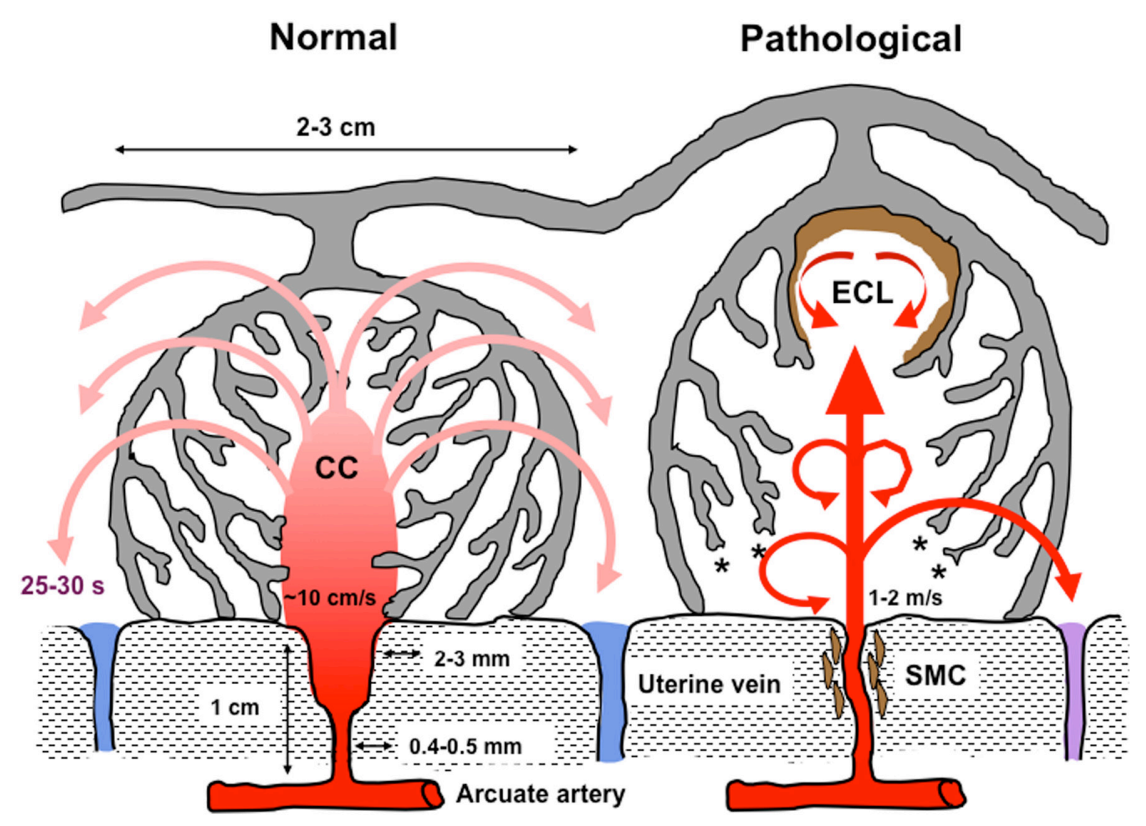

Figure 2 Diagrammatic representation of blood flow through a normal lobule and the consequences of deficient spiral artery remodelling in pathological cases. Dilation of the terminal part of the spiral artery reduces the velocity of inflow to $\sim 10 \mathrm{~cm} / \mathrm{s}$. The momentum of the inflowing blood is still sufficient to mould a central cavity (CC) within the lobule, which allows for even dispersion of the blood through the villous tree. Transit time has been estimated from radioangiography to be 25-30 s, allowing adequate opportunity for maternal-foetal exchange. In pathological cases, maternal blood enters the intervillous space in jet-like spurts at $1-2 \mathrm{~m} / \mathrm{s}$ due to deficient remodelling. The high velocity ruptures the attachments of anchoring villi (asterisks), leading to an increase in placental thickness and a globular shape. The high momentum also generates villus-free echogenic cystic lesions (ECL) that are often lined by thrombus due to more turbulent flow. Shunting of maternal blood may occur, leading to a higher oxygen content in the uterine vein (bottom right) than normal (modified from Burton et al. (2009) with permission). 


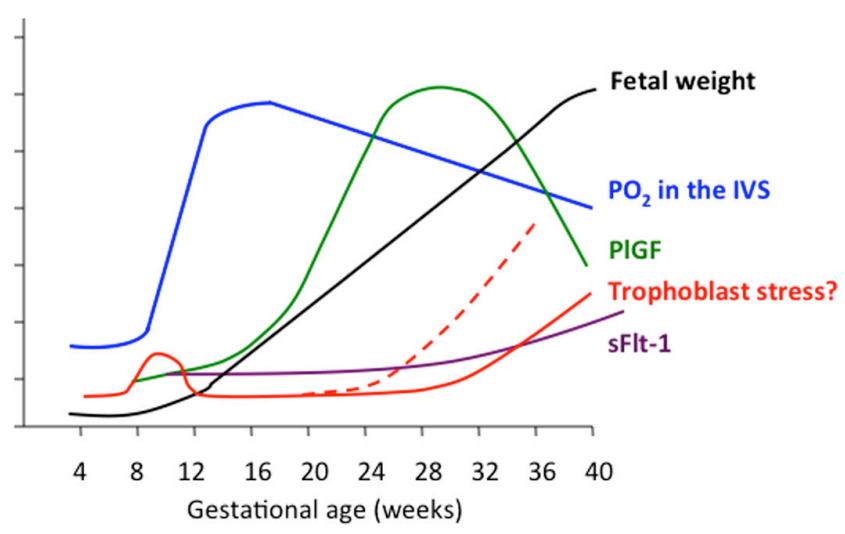

Figure 3 Schematic representation of changes in $\mathrm{O}_{2}$ concentration in the intervillous space (IVS) of the placenta, foetal weight and maternal concentrations of sFlt- 1 and PIGF across gestational age. The $\mathrm{O}_{2}$ concentration in the intervillous space rises towards the end of the first trimester and then slowly falls towards term as foetoplacental extraction increases. A burst of oxidative stress is observed in the trophoblast at the end of the first trimester, associated with onset of the maternal arterial circulation, and may rise towards term as sub-clinical uterine contractions, and a progressive mismatch between maternal supply and foeto-placental demand causes fluctuations in oxygenation. Placental secretion of sFlt-1 is positively regulated by oxidative stress, while that of PIGF is negatively regulated by ER stress. Placental stress may be exacerbated in cases of early-onset pre-eclampsia (dashed line) due to malperfusion secondary to deficient remodelling of the spiral arteries (reproduced from Burton et al. (2017a) with permission).

Unfortunately, this hypothesis cannot be tested directly by longitudinal sampling in the human, but some evidence to support it comes from the progressive accumulation of oxidatively damaged nuclei within the syncytiotrophoblast in the form of syncytial knots (Fogarty et al. 2013). Furthermore, striking changes associated with aging are observed in the post-mature placenta, when it might be expected that the mismatch between maternal supply and foeto-placental demands is greatest. Oxidised DNA and lipids and the expression of markers of senescence, such as p21, p16 and cGAMP, are all greatly increased (Maiti et al. 2017, CindrovaDavies et al. 2018).

\section{Placental oxygenation in complications of pregnancy}

The major common complications of human pregnancy form a spectrum of disorders associated with different degrees of deficiency in EVT invasion (Brosens et al. 2011, 2019). As discussed earlier, trophoblast proliferation and invasion are closely interlinked. The cells at the proximal end of a cytotrophoblast cell column proliferate during the first trimester and feed into the cytotrophoblastic shell. It is from the shell that the endovascular trophoblast that plugs the spiral arteries during the first trimester is derived. If development of the shell is impoverished, the plugs are less extensive than normal (Hustin et al. 1990), and there is a precocious and spatially disorganised onset of the maternal arterial circulation to the placenta (Jauniaux et al. 2003). This is associated with widespread oxidative damage to the placenta, leading to extensive degeneration of the syncytiotrophoblast and spontaneous pregnancy loss (Hempstock et al. 2003a). Histologically, there are close parallels between the physiological villous regression seen during formation of the chorion laeve and the pathological changes seen in spontaneous miscarriage. Both processes are induced by elevated oxygen concentrations at an early stage of pregnancy.

Poor development of the shell is also associated with an increased risk of intrauterine haematomas at the placental-maternal interface. If the haematoma extends under the basal plate, it can lead to detachment of the placenta and pregnancy loss, which is observed in around $10 \%$ of the cases within $48 \mathrm{~h}$ of the first bleeding episode (Burton \& Jauniaux 2017). In the majority of pregnancies that continue, there is an increased risk (1.9-3.7) of premature rupture of the membranes and pre-term delivery (Jauniaux et al. 2010). We have speculated that this is due to the resolving clot lying against the membranes causing local oxidative stress, which may weaken the membranes through induction of senescent changes. In addition, the clot may cause a sterile inflammation within the endometrium, stimulating contractions (Burton \& Jauniaux 2017).

Less major impairment of EVT proliferation and invasion will result in an ongoing pregnancy but with deficient spiral artery remodelling. The arteries remain of narrow calibre and surrounded by smooth muscle (Brosens et al. 2011). In the past, it has widely been assumed that this restricts maternal inflow into the placenta, which as a result is hypoxic. There are, however, no in vivo measurements to support the claim of placental hypoxia, and it should be remembered that placental hypoxia is not always synonymous with foetal hypoxia (Kingdom \& Kaufmann 1997). Nonetheless, the presence of placental oxidative stress has often been put forward to support the concept of hypoxia in pathological pregnancies. While exposure of rats to reduced oxygen levels (13\%) during pregnancy does result in an increase in markers of oxidative stress (Richter et al. 2012), these responses are not specific to hypoxia but generic to a variety of types of malperfusion, such as high shear rates or intermittent perfusion.

Mathematical modelling has revealed that the impact of deficient spiral remodelling per se on the volume of maternal inflow is relatively small due to the fact that upstream non-remodelled sections of the utero-placental vasculature are rate limiting (Burton et al. 2009). Instead, remodelling causes an order of magnitude reduction in the velocity with which the maternal blood enters the placenta, preventing damage to the delicate villous trees and ensuring even perfusion of the lobule. Hence, 
deficient remodelling is associated with jet-like spurts of maternal blood entering the placenta (Collins et al. 2012), the hose-effect. The velocity and momentum of the inflowing blood may exert several effects. First, it may gouge out high-velocity channels that bypass much of the placental villous tissue and shunt the maternal blood into the uterine veins (Fig. 2). Such channels can be visualised on ultrasonography as irregular areas of decreased echogenicity (see Burton \& Jauniaux 2018 for video). Consequently perfusion is likely to be uneven, with some areas being hyperoxic and some relatively hypoxic. Although only a small number of cases have been investigated, MRI of patients with pre-eclampsia at 33-34 weeks of gestation shows greater heterogeneity of $\mathrm{T} 2 *$ signals that reflect oxygenation than controls, with fewer, isolated areas of high intensity rapidly decaying peripherally (Hutter et al. 2019). Shunting of maternal blood through the intervillous space will reduce both the villous surface area available for exchange and the transit time, limiting gaseous transfer. These effects may explain the reduced foetal extraction of oxygen (Cetin et al. 2020) and the higher oxygen concentration in the uterine vein draining the placenta (Pardi et al. 1992), in cases of growth restriction compared to controls.

Second, the force of the jets may rupture the cytotrophoblast cell columns that form the attachments of the anchoring villi to the basal plate (Fig. 2). This will allow the chorionic and basal plates to move apart, increasing the thickness of the placenta and creating a more globular and jelly-like appearance (Burton \& Jauniaux 2018, Kingdom et al. 2018).

Third, the high shear rates, coupled with possible intermittent perfusion due to the retention of smooth muscle within the vessel walls, lead to oxidative stress, which is a hallmark of the placenta in pre-eclampsia and to a lesser extent in growth restriction (Myatt \& Cui 2004, Schoots et al. 2018). Oxidative stress induces senescence, and many of the changes observed in the post-mature placenta are also seen in placentas from cases of pre-eclampsia, growth restriction and stillbirth (Maiti et al. 2017, Cindrova-Davies et al. 2018).

Deficient remodelling can, however, lead to acute atherosis, when the lumen of the spiral artery is partially or completely obliterated by an accumulation of fibrinoid and lipid-laden macrophages (Fosheim et al. 2019). In these cases, maternal blood flow is severely impaired, which results in placental ischaemia and frank infarction. Placental infarcts of varying ages, thromboses within the intervillous space, extensive fibrin deposition and maternal floor infarction are characteristic features of severe, early-onset growth restriction with or without pre-eclampsia (Burton \& Jauniaux 2018) and are indicative of maternal vascular malperfusion (Khong et al. 2016).

The distinction between early- and late-onset pre-eclampsia is increasingly recognised and is important in the context of placental oxygenation. Mounting evidence indicates significant differences in maternal perfusion (Sohlberg et al. 2014a), gross placental pathology (Nelson et al. 2014), metabolism (Sohlberg et al. 2014b), oxidative (Daglar et al. 2016) and the closely related endoplasmic reticulum stress (Yung et al. 2014) and many other markers between the two subcategories (Burton et al. 2019). In the absence of in vivo measurements, malperfusion is a more robust explanation for the changes seen in early-onset preeclampsia, but the stage of pregnancy at which the pathophysiology starts is uncertain (Fig. 2). It might be expected that onset of the maternal circulation is abnormal due to deficient EVT invasion and 'plugging' of these vessels. The most extreme example of this is seen in cases of early pregnancy failure, when onset of the maternal circulation is both precocious and disorganised, occurring throughout the placenta simultaneously and generating overwhelming oxidative stress (Hempstock et al. 2003a, Jauniaux et al. 2003). Further high-resolution imaging may resolve this issue. In the meantime, the often cited, but circular, argument that in pre-eclampsia the placenta is hypoxic, causing impaired trophoblast invasion, leading to placental hypoxia should be abandoned.

Mitochondria are an important source of ROS, and mitochondrial dysfunction with a decrease in oxidative phosphorylation capacity has been reported in both early-onset and late-onset pre-eclampsia (Muralimanoharan et al. 2012, Yung et al. 2019). In early-onset pre-eclampsia the protein levels of the electron transport complexes were unchanged, but there was evidence of activation of a non-canonical mitochondrial unfolded protein response implying loss of function. These findings could be recapitulated by subjecting BeWo cells to cycles of hypoxiareoxygenation (Yung et al. 2019). In late-onset preeclampsia, the reduction in respiration was associated with an increase in HIF- $1 \alpha$ and the hypoxia-induced miR 210 that disrupts assembly of components of the electron transport chain (Muralimanoharan et al. 2012). However, DNA binding of HIF was decreased, and it was proposed that stabilisation of HIF was through the increased ROS rather than hypoxia.

\section{Conclusion}

The placental tissues experience a major increase in oxygenation with full onset of the maternal arterial circulation during the transition from the first to the second trimester. The low-oxygen environment during the first trimester favours stemness and proliferation of the trophoblast lineage, and there is no evidence that the tissues are hypoxically stressed. Rather, it appears that the tissues are challenged by the rise in $\mathrm{O}_{2}$ and that they respond by increasing their antioxidant defences. Later in pregnancy, as feto-placental demand begins 
to outstrip maternal supply the placenta becomes increasingly stressed, leading to senescence changes. These are particularly marked in the post-term placenta. In pathological pregnancies, maternal malperfusion is likely a more powerful stimulus for the changes observed than hypoxia alone. Further research involving imaging of placental metabolites using MRI, near infrared spectroscopy (Hasegawa et al. 2010) and computational modelling (Nye et al. 2018) may shed greater light on placental oxygenation in normal and pathological pregnancies in the future.

\section{Declaration of interest}

The authors declare that there is no conflict of interest that could be perceived as prejudicing the impartiality of this review.

\section{Funding}

Preparation of this review did not receive any specific grant from any funding agency in the public, commercial or not-forprofit sector.

\section{Author contribution statement}

G J B wrote the first draft. All authors contributed to, and approved, the final version.

\section{References}

Apps R, Sharkey A, Gardner L, Male V, Trotter M, Miller N, North R, Founds S \& Moffett A 2011 Genome-wide expression profile of first trimester villous and extravillous human trophoblast cells. Placenta $\mathbf{3 2}$ 33-43. (https://doi.org/10.1016/j.placenta.2010.10.010)

Bontekoe S, Mantikou E, van Wely M, Seshadri S, Repping S \& Mastenbroek S 2012 Low oxygen concentrations for embryo culture in assisted reproductive technologies. Cochrane Database of Systematic Reviews 7 CD008950. (https://doi.org/10.1002/14651858.CD008950. pub2)

Brosens I, Pijnenborg R, Vercruysse L \& Romero R 2011 The 'great obstetrical syndromes' are associated with disorders of deep placentation. American Journal of Obstetrics and Gynecology 204 193-201. (https:// doi.org/10.1016/j.ajog.2010.08.009)

Brosens I, Puttemans P \& Benagiano G 2019 Placental bed research: I. The placental bed: From spiral arteries remodeling to the great obstetrical syndromes. American Journal of Obstetrics and Gynecology 221 437-456. (https://doi.org/10.1016/j.ajog.2019.05.044)

Burton GJ \& Jauniaux E 2017 The cytotrophoblastic shell and complications of pregnancy. Placenta 60 134-139. (https://doi.org/10.1016/j. placenta.2017.06.007)

Burton GJ \& Jauniaux E 2018 Pathophysiology of placental-derived fetal growth restriction. American Journal of Obstetrics and Gynecology 218 S745-S761. (https://doi.org/10.1016/j.ajog.2017.11.577)

Burton GJ, Jauniaux E \& Watson AL 1999 Maternal arterial connections to the placental intervillous space during the first trimester of human pregnancy; the Boyd collection revisited. American Journal of Obstetrics and Gynecology 181 718-724. (https://doi.org/10.1016/s00029378(99)70518-1)

Burton GJ, Watson AL, Hempstock J, Skepper JN \& Jauniaux E 2002 Uterine glands provide histiotrophic nutrition for the human fetus during the first trimester of pregnancy. Journal of Clinical Endocrinology and Metabolism 87 2954-2959. (https://doi.org/10.1210/jcem.87.6.8563)

Burton GJ, Woods AW, Jauniaux E \& Kingdom JC 2009 Rheological and physiological consequences of conversion of the maternal spiral arteries for uteroplacental blood flow during human pregnancy. Placenta 30 473-482. (https://doi.org/10.1016/j.placenta.2009.02.009)

Burton GJ, Jauniaux E \& Charnock-Jones DS 2010 The influence of the intrauterine environment on human placental development. International Journal of Developmental Biology 54 303-312. (https://doi.org/10.1387/ ijdb.082764gb)

Burton GJ, Yung HW \& Murray AJ 2017a Mitochondrial - endoplasmic reticulum interactions in the trophoblast: stress and senescence. Placenta 52 146-155. (https://doi.org/10.1016/j.placenta.2016.04.001)

Burton GJ, Jauniaux E \& Murray AJ 2017b Oxygen and placental development; parallels and differences with tumour biology. Placenta 56 14-18. (https://doi.org/10.1016/j.placenta.2017.01.130)

Burton GJ, Redman CW, Roberts JM \& Moffett A 2019 Pre-eclampsia: pathophysiology and clinical implications. BMJ 366 |2381. (https://doi. org/10.1136/bmj.I2381)

Burton GJ, Cindrova-Davies T \& Turco MY 2020 Review: Histotrophic nutrition and the placental-endometrial dialogue during human early pregnancy. Placenta. (https://doi.org/10.1016/j.placenta.2020.02.008)

Caniggia I, Mostachfi H, Winter J, Gassmann M, Lye SJ, Kuliszewski M \& Post $\mathbf{M} 2000$ Hypoxia-inducible factor-1 mediates the biological effects of oxygen on human trophoblast differentiation through tgfbeta(3). Journal of Clinical Investigation 105 577-587. (https://doi.org/10.1172/JCl8316)

Cetin I, Taricco E, Mando C, Radaelli T, Boito S, Nuzzo AM \& Giussani DA 2020 Fetal oxygen and glucose consumption in human pregnancy complicated by fetal growth restriction. Hypertension 75 748-754. (https://doi.org/10.1161/HYPERTENSIONAHA.119.13727)

Chang CW, Wakeland AK \& Parast MM 2018 Trophoblast lineage specification, differentiation and their regulation by oxygen tension. Journal of Endocrinology 236 R43-R56. (https://doi.org/10.1530/JOE17-0402)

Cindrova-Davies T, Yung HW, Johns J, Spasic-Boskovic O, Korolchuk S, Jauniaux E, Burton GJ \& Charnock-Jones DS 2007 Oxidative stress, gene expression, and protein changes induced in the human placenta during labor. American Journal of Pathology 171 1168-1179. (https:// doi.org/10.2353/ajpath.2007.070528)

Cindrova-Davies T, van Patot MT, Gardner L, Jauniaux E, Burton GJ \& Charnock-Jones DS 2015 Energy status and hif signalling in chorionic villi show no evidence of hypoxic stress during human early placental development. Molecular Human Reproduction 21 296-308. (https://doi. org/10.1093/molehr/gau105)

Cindrova-Davies T, Fogarty NME, Jones CJP, Kingdom J \& Burton GJ 2018 Evidence of oxidative stress-induced senescence in mature, post-mature and pathological human placentas. Placenta 68 15-22. (https://doi. org/10.1016/j.placenta.2018.06.307)

Collins SL, Birks JS, Stevenson GN, Papageorghiou AT, Noble JA \& Impey L 2012 Measurement of spiral artery jets: general principles and differences observed in small-for-gestational-age pregnancies. Ultrasound in Obstetrics and Gynecology 40 171-178. (https://doi. org/10.1002/uog.10149)

Cox LS \& Redman C 2017 The role of cellular senescence in ageing of the placenta. Placenta 52 139-145. (https://doi.org/10.1016/j. placenta.2017.01.116)

Daglar K, Kirbas A, Timur H, Ozturk Inal Z \& Danisman N 2016 Placental levels of total oxidative and anti-oxidative status, adamts-12 and decorin in early- and late-onset severe preeclampsia. Journal of Maternal-Fetal and Neonatal Medicine 29 4059-4064. (https://doi.org/10.3109/14767 058.2016.1154942)

Espinoza J, Sebire NJ, McAuliffe F, Krampl E \& Nicolaides KH 2001 Placental villus morphology in relation to maternal hypoxia at high altitude. Placenta 22 606-608. (https://doi.org/10.1053/plac.2001.0696)

Ezashi T, Das P \& Roberts RM 2005 Low o2 tensions and the prevention of differentiation of hes cells. PNAS 102 4783-4788. (https://doi. org/10.1073/pnas.0501283102)

Fogarty NM, Ferguson-Smith AC \& Burton GJ 2013 Syncytial knots (Tenney-parker changes) in the human placenta: evidence of loss of transcriptional activity and oxidative damage. American Journal of Pathology 183 144-152. (https://doi.org/10.1016/j.ajpath.2013.03.016) 
Forristal CE, Christensen DR, Chinnery FE, Petruzzelli R, Parry KL, Sanchez-Elsner T \& Houghton FD 2013 Environmental oxygen tension regulates the energy metabolism and self-renewal of human embryonic stem cells. PLOS ONE 8 e62507. (https://doi.org/10.1371/journal. pone.0062507)

Fosheim IK, Alnaes-Katjavivi P, Redman C, Roald B, Staff AC \& Storvold GL 2019 Acute atherosis of decidua basalis; characterization of spiral arteries, endothelial status and activation. Placenta 82 10-16. (https:// doi.org/10.1016/j.placenta.2019.04.006)

Fox H 1967 The incidence and significance of vasculo-syncytial membranes in the human placenta. Journal of Obstetrics and Gynaecology of the British Commonwealth 74 28-33. (https://doi. org/10.1111/j.1471-0528.1967.tb03928.x)

Gelo N, Kirinec G, Baldani DP, Vrcic H, Jezek D, Milosevic M \& Stanic P 2019 Influence of human embryo cultivation in a classic $\mathrm{CO}_{2}$ incubator with $20 \%$ oxygen versus benchtop incubator with $5 \%$ oxygen on live births: the randomized prospective trial. Zygote 27 131-136. (https:// doi.org/10.1017/S0967199418000618)

Genbacev O, Joslin R, Damsky CH, Polliotti BM \& Fisher SJ 1996 Hypoxia alters early gestation human cytotrophoblast differentiation/invasion in vitro and models the placental defects that occur in preeclampsia. Journal of Clinical Investigation 97 540-550. (https://doi.org/10.1172/ JCI118447)

Genbacev O, Zhou Y, Ludlow JW \& Fisher SJ 1997 Regulation of human placental development by oxygen tension. Science 277 1669-1672. (https://doi.org/10.1126/science.277.5332.1669)

Gorr TA 2017 Hypometabolism as the ultimate defence in stress response: how the comparative approach helps understanding of medically relevant questions. Acta Physiologica 219 409-440. (https://doi. org/10.1111/apha.12747)

Graham CH, Postovit LM, Park H, Canning MT \& Fitzpatrick TE 2000 Adriana and luisa castellucci award lecture 1999: role of oxygen in the regulation of trophoblast gene expression and invasion. Placenta $\mathbf{2 1}$ 443-450. (https://doi.org/10.1053/plac.2000.0543)

Haider S, Meinhardt G, Saleh L, Fiala C, Pollheimer J \& Knofler M 2016 Notch1 controls development of the extravillous trophoblast lineage in the human placenta. PNAS 113 E7710-E7719. (https://doi.org/10.1073/ pnas.1612335113)

Haider S, Pollheimer J \& Knofler M 2017 Notch signalling in placental development and gestational diseases. Placenta $\mathbf{5 6}$ 65-72. (https://doi org/10.1016/j.placenta.2017.01.117)

Haider S, Meinhardt G, Saleh L, Kunihs V, Gamperl M, Kaindl U, Ellinger A, Burkard TR, Fiala C, Pollheimer J et al. 2018 Self-renewing trophoblast organoids recapitulate the developmental program of the early human placenta. Stem Cell Reports 11 537-551. (https://doi.org/10.1016/j. stemcr.2018.07.004)

Hamilton WJ \& Boyd JD 1960 Development of the human placenta in the first three months of gestation. Journal of Anatomy 94 297-328.

Hasegawa J, Nakamura M, Matsuoka R, Mimura T, Ichizuka K, Sekizawa A \& Okai T 2010 Evaluation of placental function using near infrared spectroscopy during fetal growth restriction. Journal of Perinatal Medicine 38 29-32. (https://doi.org/10.1515/jpm.2010.003)

Hemberger M, Udayashankar R, Tesar P, Moore H \& Burton GJ 2010 Elf5-enforced transcriptonal networks define an epigentically regulated trophoblast stem cell compartment in the human placenta. Human Molecular Genetics 19 2456-2467.

Hempstock J, Jauniaux E, Greenwold N \& Burton GJ 2003a The contribution of placental oxidative stress to early pregnancy failure. Human Pathology 34 1265-1275. (https://doi.org/10.1016/j.humpath.2003.08.006)

Hempstock J, Bao YP, Bar-Issac M, Segaren N, Watson AL, Charnock Jones DS, Jauniaux E \& Burton GJ 2003b Intralobular differences in antioxidant enzyme expression and activity reflect oxygen gradients within the human placenta. Placenta 24 517-523. (https://doi. org/10.1053/plac.2002.0955)

Hochachka PW \& Lutz PL 2001 Mechanism, origin, and evolution of anoxia tolerance in animals. Comparative Biochemistry and Physiology: Part B, Biochemistry and Molecular Biology 130 435-459. (https://doi. org/10.1016/s1096-4959(01)00408-0)

Hung TH, Skepper JN \& Burton GJ 2001 In vitro ischemia-reperfusion injury in term human placenta as a model for oxidative stress in pathological pregnancies. American Journal of Pathology 159 1031-1043. (https://doi.org/10.1016/S0002-9440(10)61778-6)
Hustin J \& Schaaps JP 1987 Echographic and anatomic studies of the maternotrophoblastic border during the first trimester of pregnancy. American Journal of Obstetrics and Gynecology 157 162-168. (https:// doi.org/10.1016/s0002-9378(87)80371-x)

Hustin J, Schaaps JP \& Lambotte R 1988 Anatomical studies of the uteroplacental vascularisation in the first trimester of pregnancy. Trophoblast Research 3 49-60.

Hustin J, Jauniaux E \& Schaaps JP 1990 Histological study of the maternoembryonic interface in spontaneous abortion. Placenta 11 477-486. (https://doi.org/10.1016/s0143-4004(05)80193-6)

Hutter J, Slator PJ, Jackson L, Gomes ADS, Ho A, Story L, O'Muircheartaigh J, Teixeira RPAG, Chappell LC, Alexander DC et al. 2019 Multi-modal functional mri to explore placental function over gestation. Magnetic Resonance in Medicine 81 1191-1204. (https://doi. org/10.1002/mrm.27447)

Hutter J, Harteveld AA, Jackson LH, Franklin S, Bos C, van Osch MJP, O'Muircheartaigh J, Ho A, Chappell L, Hajnal JV et al. 2020 Perfusion and apparent oxygenation in the human placenta (perfox). Magnetic Resonance in Medicine 83 549-560. (https://doi.org/10.1002/mrm.27950)

James JL, Stone PR \& Chamley LW 2006 The effects of oxygen concentration and gestational age on extravillous trophoblast outgrowth in a human first trimester villous explant model. Human Reproduction 212699 2705. (https://doi.org/10.1093/humrep/del212)

Jauniaux E, Jurkovic D \& Campbell S 1991 In vivo investigations of anatomy and physiology of early human placental circulations. Ultrasound in Obstetrics and Gynecology 1 435-445. (https://doi.org/10.1046/j.14690705.1991.01060435.x)

Jauniaux E, Watson AL, Hempstock J, Bao YP, Skepper JN \& Burton GJ 2000 Onset of maternal arterial bloodflow and placental oxidative stress; a possible factor in human early pregnancy failure. American Journal of Pathology 157 2111-2122. (https://doi.org/10.1016/S00029440(10)64849-3)

Jauniaux E, Watson AL \& Burton GJ 2001 Evaluation of respiratory gases and acid-base gradients in fetal fluids and uteroplacental tissue between 7 and 16 weeks. American Journal of Obstetrics and Gynecology $\mathbf{1 8 4}$ 998-1003. (https://doi.org/10.1067/mob.2001.111935)

Jauniaux E, Hempstock J, Greenwold N \& Burton GJ 2003 Trophoblastic oxidative stress in relation to temporal and regional differences in maternal placental blood flow in normal and abnormal early pregnancies. American Journal of Pathology 162 115-125. (https://doi. org/10.1016/S0002-9440(10)63803-5)

Jauniaux E, Hempstock J, Teng C, Battaglia FC \& Burton GJ 2005 Polyol concentrations in the fluid compartments of the human conceptus during the first trimester of pregnancy; maintenance of redox potential in a low oxygen environment. Journal of Clinical Endocrinology and Metabolism 90 1171-1175. (https://doi.org/10.1210/jc.2004-1513)

Jauniaux E, Van Oppenraaij RH \& Burton GJ 2010 Obstetric outcome after early placental complications. Current Opinion in Obstetrics and Gynecology 22 452-457. (https://doi.org/10.1097/ GCO.0b013e3283404e44)

Jiang B, Kamat A \& Mendelson CR 2000 Hypoxia Prevents Induction of Aromatase Expression in Human Trophoblast Cells in Culture: Potential Inhibitory Role of the Hypoxia-Inducible Transcription Factor Mash2 (Mammalian Achaete-Scute Homologous Protein-2). Molecular Endocrinology 14 1661-1673. (https://doi.org/10.1210/mend.14.10.0539)

Khong TY, Mooney EE, Ariel I, Balmus NC, Boyd TK, Brundler MA, Derricott H, Evans MJ, Faye-Petersen OM, Gillan JE et al. 2016 Sampling and definitions of placental lesions: Amsterdam placental workshop group consensus statement. Archives of Pathology and Laboratory Medicine 140 698-713. (https://doi.org/10.5858/arpa.2015-0225-CC)

Kilburn BA, Wang J, Duniec-Dmuchowski ZM, Leach RE, Romero R \& Armant DR 2000 Extracellular matrix composition and hypoxia regulate the expression of HLA-G and integrins in a human trophoblast cell line. Biology of Reproduction 62 739-747. (https://doi.org/10.1095/ biolreprod62.3.739)

Kingdom JCP \& Kaufmann P 1997 Oxygen and placental villous development: origins of fetal hypoxia. Placenta 18 613-621; discussion 623. (https://doi.org/10.1016/s0143-4004(97)90000-x)

Kingdom JC, Audette MC, Hobson SR, Windrim RC \& Morgen E 2018 A placenta clinic approach to the diagnosis and management of fetal growth restriction. American Journal of Obstetrics and Gynecology 218 S803-S817. (https://doi.org/10.1016/j.ajog.2017.11.575) 
Lash GE, Otun HA, Innes BA, Bulmer JN, Searle RF \& Robson SC 2006 Low oxygen concentrations inhibit trophoblast cell invasion from early gestation placental explants via alterations in levels of the urokinase plasminogen activator system. Biology of Reproduction 74 403-409. (https://doi.org/10.1095/biolreprod.105.047332)

Lash GE, Hornbuckle J, Brunt A, Kirkley M, Searle RF, Robson SC \& Bulmer JN 2007 Effect of low oxygen concentrations on trophoblastlike cell line invasion. Placenta 28 390-398. (https://doi.org/10.1016/j. placenta.2006.06.001)

Leese HJ 2002 Quiet please, do not disturb; a hypothesis of embryo metabolism and viability. BioEssays 24 845-849. (https://doi. org/10.1002/bies.10137)

Lees JG, Gardner DK \& Harvey AJ 2017 Pluripotent stem cell metabolism and mitochondria: beyond atp. Stem Cells International 20172874283. (https://doi.org/10.1155/2017/2874283)

Lengner CJ, Gimelbrant AA, Erwin JA, Cheng AW, Guenther MG, Welstead GG, Alagappan R, Frampton GM, Xu P, Muffat J et al. 2010 Derivation of pre-x inactivation human embryonic stem cells under physiological oxygen concentrations. Cell 141 872-883. (https://doi. org/10.1016/j.cell.2010.04.010)

Maiti K, Sultana Z, Aitken RJ, Morris J, Park F, Andrew B, Riley SC \& Smith R 2017 Evidence that fetal death is associated with placental aging. American Journal of Obstetrics and Gynecology 217 441.e1-441. e14. (https://doi.org/10.1016/j.ajog.2017.06.015)

Mizuuchi M, Cindrova-Davies T, Olovsson M, Charnock-Jones DS, Burton GJ \& Yung HW 2016 Placental endoplasmic reticulum stress negatively regulates transcription of placental growth factor via atf4 and atf6beta: implications for the pathophysiology of human pregnancy complications. Journal of Pathology 238 550-561. (https://doi. org/10.1002/path.4678)

Moffett A, Hiby SE \& Sharkey AM 2015 The role of the maternal immune system in the regulation of human birthweight. Philosophical Transactions of the Royal Society of London: Series B, Biological Sciences 370 20140071. (https://doi.org/10.1098/rstb.2014.0071)

Muralimanoharan S, Maloyan A, Mele J, Guo C, Myatt LG \& Myatt L 2012 Mir-210 modulates mitochondrial respiration in placenta with preeclampsia. Placenta 33 816-823. (https://doi.org/10.1016/j. placenta.2012.07.002)

Myatt L \& Cui X 2004 Oxidative stress in the placenta. Histochemistry and Cell Biology 122 369-382. (https://doi.org/10.1007/s00418-004-0677-x)

Nayeem SB, Arfuso F, Dharmarajan A \& Keelan JA 2016 Role of wnt signalling in early pregnancy. Reproduction, Fertility, and Development 28 525-544. (https://doi.org/10.1071/RD14079)

Nelson DB, Ziadie MS, Mclntire DD, Rogers BB \& Leveno KJ 2014 Placental pathology suggesting that preeclampsia is more than one disease. American Journal of Obstetrics and Gynecology 210 66.e1-66. e7. (https://doi.org/10.1016/j.ajog.2013.09.010)

Nye GA, Ingram E, Johnstone ED, Jensen OE, Schneider H, Lewis RM, Chernyavsky IL \& Brownbill P 2018 Human placental oxygenation in late gestation: experimental and theoretical approaches. Journal of Physiology 596 5523-5534. (https://doi.org/10.1113/JP275633)

Okae H, Toh H, Sato T, Hiura H, Takahashi S, Shirane K, Kabayama Y, Suyama M, Sasaki H \& Arima T 2018 Derivation of human trophoblast stem cells. Cell Stem Cell 22 50.e6-63.e6. (https://doi.org/10.1016/j. stem.2017.11.004)

Ottosen LD, Hindkaer J, Husth M, Petersen DE, Kirk J \& Ingerslev HJ 2006 Observations on intrauterine oxygen tension measured by fibre-optic microsensors. Reproductive Biomedicine Online 13 380-385. (https:// doi.org/10.1016/s1472-6483(10)61443-5)

Pardi G, Cetin I, Marconi AM, Bozzetti P, Buscaglia M, Makowski EL \& Battaglia FC 1992 Venous drainage of the human uterus: respiratory gas studies in normal and fetal growth-retarded pregnancies. American Journal of Obstetrics and Gynecology 166 699-706. (https://doi. org/10.1016/0002-9378(92)91700-k)

Pijnenborg R, Vercruysse L \& Hanssens M 2006 The uterine spiral arteries in human pregnancy: facts and controversies. Placenta 27 939-958. (https://doi.org/10.1016/j.placenta.2005.12.006)

Pringle KG, Kind KL, Sferruzzi-Perri AN, Thompson JG \& Roberts CT 2010 Beyond oxygen: complex regulation and activity of hypoxia inducible factors in pregnancy. Human Reproduction Update 16 415-431. (https:// doi.org/10.1093/humupd/dmp046)
Richter HG, Camm EJ, Modi BN, Naeem F, Cross CM, Cindrova-Davies T, Spasic-Boskovic O, Dunster C, Mudway IS, Kelly FJ et al. 2012 Ascorbate prevents placental oxidative stress and enhances birth weight in hypoxic pregnancy in rats. Journal of Physiology 590 1377-1387. (https://doi. org/10.1113/jphysiol.2011.226340)

Roberts VHJ, Morgan TK, Bednarek P, Morita M, Burton GJ, Lo JO \& Frias AE 2017 Early first trimester uteroplacental flow and the progressive disintegration of spiral artery plugs: new insights from contrast-enhanced ultrasound and tissue histopathology. Human Reproduction 32 2382-2393. (https://doi.org/10.1093/humrep/ dex301)

Rodesch F, Simon P, Donner C \& Jauniaux E 1992 Oxygen measurements in endometrial and trophoblastic tissues during early pregnancy. Obstetrics and Gynecology $80283-285$.

Schaaps JP \& Hustin J 1988 In vivo aspect of the maternal-trophoblastic border during the first trimester of gestation. Trophoblast Research $\mathbf{3}$ 39-48.

Schaaps JP, Tsatsaris V, Goffin F, Brichant JF, Delbecque K, Tebache M, Collignon L, Retz MC \& Foidart JM 2005 Shunting the intervillous space: new concepts in human uteroplacental vascularization. American Journal of Obstetrics and Gynecology 192 323-332. (https:// doi.org/10.1016/j.ajog.2004.06.066)

Schoots MH, Gordijn SJ, Scherjon SA, van Goor H \& Hillebrands JL 2018 Oxidative stress in placental pathology. Placenta 69 153-161. (https:// doi.org/10.1016/j.placenta.2018.03.003)

Sinding M, Peters DA, Frokjaer JB, Christiansen OB, Uldbjerg N \& Sorensen A 2016 Reduced placental oxygenation during subclinical uterine contractions as assessed by bold mri. Placenta 39 16-20. (https:// doi.org/10.1016/j.placenta.2015.12.018)

Sohlberg S, Mulic-Lutvica A, Lindgren P, Ortiz-Nieto F, Wikstrom AK \& Wikstrom J 2014a Placental perfusion in normal pregnancy and early and late preeclampsia: a magnetic resonance imaging study. Placenta 35 202-206. (https://doi.org/10.1016/j.placenta.2014.01.008)

Sohlberg S, Wikstrom AK, Olovsson M, Lindgren P, Axelsson O, MulicLutvica A, Weis J \& Wikstrom J 2014b In vivo 31p-mr spectroscopy in normal pregnancy, early and late preeclampsia: a study of placental metabolism. Placenta 35 318-323.

Soothill PW, Nicolaides KH, Rodeck CH \& Campbell S 1986 Effect of gestational age on fetal and intervillous blood gas and acid-base values in human pregnancy. Fetal Therapy 1 168-175. (https://doi. org/10.1159/000262264)

Steptoe PC, Edwards RG \& Purdy JM 1971 Human blastocysts grown in culture. Nature 229 132-133. (https://doi.org/10.1038/229132a0)

Treissman J, Yuan V, Baltayeva J, Le HT, Castellana B, Robinson WP \& Beristain AG 2020 Low oxygen enhances trophoblast column growth by potentiating differentiation of the extravillous lineage and promoting lox activity. Development 147 dev181263. (https://doi.org/10.1242/ dev.181263)

Turco MY, Gardner L, Kay RG, Hamilton RS, Prater M, Hollinshead MS, McWhinnie A, Esposito L, Fernando R, Skelton H et al. 2018 Trophoblast organoids as a model for maternal-fetal interactions during human placentation. Nature 564 263-267. (https://doi.org/10.1038/s41586018-0753-3)

Van Montfoort APA, Arts EGJM, Wijnandts L, Sluijmer A, Pelinck MJ, Land JA \& Van Echten-Arends J 2020 Reduced oxygen concentration during human ivf culture improves embryo utilization and cumulative pregnancy rates per cycle. Human Reproduction Open 2020 hoz036. (https://doi.org/10.1093/hropen/hoz036)

Wakeland AK, Soncin F, Moretto-Zita M, Chang CW, Horii M, Pizzo D, Nelson KK, Laurent LC \& Parast MM 2017 Hypoxia directs human extravillous trophoblast differentiation in a hypoxia-inducible factordependent manner. American Journal of Pathology 187 767-780. (https://doi.org/10.1016/j.ajpath.2016.11.018)

Wouters BG, van den Beucken T, Magagnin MG, Koritzinsky M, Fels D \& Koumenis C 2005 Control of the hypoxic response through regulation of mRNA translation. Seminars in Cell and Developmental Biology 16 487-501. (https://doi.org/10.1016/j.semcdb.2005.03.009)

Yedwab GA, Paz G, Homonnai TZ, David MP \& Kraicer PF 1976 The temperature, ph, and partial pressure of oxygen in the cervix and uterus of women and uterus of rats during the cycle. Fertility and Sterility $\mathbf{2 7}$ 304-309. (https://doi.org/10.1016/s0015-0282(16)41722-x) 
Yung HW, Cox M, Tissot van Patot M \& Burton GJ 2012 Evidence of endoplasmic reticulum stress and protein synthesis inhibition in the placenta of non-native women at high altitude. FASEB Journal 26 1970-1981. (https://doi.org/10.1096/fj.11-190082)

Yung HW, Atkinson D, Campion-Smith T, Olovsson M, Charnock-Jones DS \& Burton GJ 2014 Differential activation of placental unfolded protein response pathways implies heterogeneity in causation of early- and lateonset pre-eclampsia. Journal of Pathology 234 262-276. (https://doi. org/10.1002/path.4394)

Yung HW, Colleoni F, Dommett E, Cindrova-Davies T, Kingdom J, Murray AJ \& Burton GJ 2019 Noncanonical mitochondrial unfolded protein response impairs placental oxidative phosphorylation in earlyonset preeclampsia. PNAS 116 18109-18118. (https://doi.org/10.1073/ pnas.1907548116)
Zhou S, Xie Y, Puscheck EE \& Rappolee DA 2011 Oxygen levels that optimize tsc culture are identified by maximizing growth rates and minimizing stress. Placenta 32 475-481. (https://doi.org/10.1016/j. placenta.2011.03.013)

Received 19 March 2020

First decision 1 May 2020

Revised manuscript received 7 May 2020

Accepted 19 May 2020 